\title{
Pengaruh Peta Pemikiran dalam Pembelajaran Berbasis Masalah terhadap Penguasaan Konsep dan Literasi Sains Siswa SMP
}

\author{
Latifah Hanim $^{1}$, Herawati Susilo ${ }^{2}$, Lia Yuliati ${ }^{3}$ \\ ${ }^{1}$ Pendidikan Dasar-Universitas Negeri Malang \\ ${ }^{2}$ Pendidikan Biologi-Universitas Negeri Malang \\ ${ }^{3}$ Pendidikan Fisika-Universitas Negeri Malang
}

\begin{tabular}{l}
\hline \hline INFO ARTIKEL \\
\hline Riwayat Artikel: \\
Diterima: $12-07-2019$ \\
Disetujui: $13-02-2020$ \\
\hline
\end{tabular}

\section{Kata kunci:}

scientific literacy; mastery of concepts; problem based learning; digestive system; literasi sains; penguasaan konsep; pembelajaran berbasis masalah, sistem pencernaan

\author{
Alamat Korespondensi: \\ Latifah Hanim \\ Pendidikan Dasar \\ Universitas Negeri Malang \\ Jalan Semarang 5 Malang \\ E-mail: hanim.ummu@gmail.com
}

\begin{abstract}
ABSTRAK
Abstract: This study aims to determine the effectiveness of PBL with thinking map on the mastery of the concept and students' scientific literacy in digestive system material, additives and addictive substances, and respiratory system in human. This quantitative study involved 94 students consisting of 3 classes, namely 31 students of class VIII C, 31 students of class VIII E and 32 students of class VIII A SMP Negeri 5 Jombang academic year 2018/2019. The results showed PBL assisted thinking map effective on mastering the concept of content dimensions and against scientific literacy in digestive system material, additives and addictive substances, and the respiratory system. The results of statistical tests showed that there were differences in the mastery of concepts and scientific literacy skills before and after using PBL assisted by thinking map on digestive system material, additives and addictive substances, and the respiratory system. The conclusion of this study is that problem-based learning assisted by thinking map has an effect on both mastery of science concepts and science literacy so that students are effectively used in junior high school on digestive system material, additives and addictive substances, and the respiratory system.

Abstrak: Penelitian ini bertujuan mengetahui keefektifan PBM berbantuan thinking map terhadap penguasaan konsep IPA dan literasi sains siswa SMP pada materi sistem pencernaan, zat aditif dan adiktif, dan sistem pernapasan pada manusia. Penelitian kuantitatif ini melibatkan 94 peserta didik terdiri atas tiga kelas, yaitu 31 peserta didik kelas VIII C, 31 peserta didik kelas VIII E dan 32 peserta didik kelas VIII A SMP Negeri 5 Jombang tahun ajaran 2018/2019. Hasil penelitian menunjukkan PBM berbantuan thinking map efektif terhadap penguasaan konsep dan literasi sains pada materi sistem pencernaan, zat aditif dan adiktif, dan sistem pernapasan. Hasil uji statistik menunjukkan terdapat perbedaan penguasaan konsep dan kemampuan literasi sains sebelum dan setelah menggunakan PBM berbantuan thinking map. Kesimpulan penelitian ini adalah pembelajaran berbasis masalah berbantuan thinking map berpengaruh baik pada penguasaan konsep IPA dan literasi sains siswa sehingga efektif digunakan di SMP pada materi sistem pencernaan, zat aditif dan adiktif, dan sistem pernapasan.
\end{abstract}

Siswa menguasai konsep apabila dapat menjawab pertanyaan terkait dengan konsep tersebut, dapat menyebutkan banyak hal yang terkait dengan konsep, mengaitkan dengan konsep-konsep yang lain, memberikan contoh yang serupa, mendefinisikan dan mengevaluasi konsep tersebut dengan kalimatnya sendiri serta mengetahui atribut-atribut kritisnya (Arends, 2012). Mendefinisikan suatu konsep dengan kata-kata dan kalimat sendiri membuat konsep lebih mudah dipelajari dan dimengerti tanpa mengubah maknanya (Purwanto, 2008). Menciptakan kegiatan pembelajaran yang efektif dapat memengaruhi penguasaan konsep siswa. Kegiatan yang dapat dilakukan, misalnya dengan melaksanakan praktikum ataupun demonstrasi (Yance, 2013). Mengembangkan rasa ingin tahu siswa terhadap sebuah fenomena melalui pertanyaan (Hidayat, 2012). Pembelajaran disesuaikan dengan cara kerja otak (Saleh, 2011). Indikator penguasaan konsep berdasarkan revisi Taksonomi Bloom terdiri dari enam domain proses kognitif (1) mengingat, (2) memahami, (3) mengaplikasikan, (4) menganalisis, (5) mengevaluasi, dan (6) mencipta (Anderson \& Krathwohl, 2001). 
Ranah kognitif pengetahuan, pemahaman, dan aplikasi termasuk berpikir tingkat rendah sedangkan analisis, sintesis, dan evaluasi termasuk berpikir tingkat tinggi (Lawrence, 1999). Berpikir tingkat tinggi dibedakan menjadi berpikir kreatif dan berpikir kritis (Krulik \& Rudnick, 1996; Johnson, 2002). Ranah kognitif menerapkan, menganalisis, mengevaluasi, dan mencipta membutuhkan penalaran siswa. Penalaran siswa yang dilandasi dengan kemampuan interpretasi dan argumentasi yang baik akan memiliki korelasi yang kuat terhadap terbentuknya kemampuan berpikir siswa diantaranya berpikir tingkat tinggi dan berpikir kritis (Ku dkk, 2014; Hasnunidah dkk, 2015). Kemampuan berpikir dan bernalar yang baik mendukung kesiapan siswa menjadi masyarakat dunia yang berkualitas di masa depan, yaitu mempunyai pemahaman yang utuh dan mampu menyelesaikan permasalahan secara efektif dalam kehidupan sehari-hari (Brown dkk, 2010; Sari dkk, 2013).

Literasi sains juga merupakan kompetensi utama abad ke 21 yang harus dimiliki siswa selama belajar IPA. Literasi sains dimulai dari menerapkan ilmu yang diperoleh untuk diri sendiri, keluarga, dan lingkungannya. Siswa yang berliterasi sains mampu mengaitkan pengetahuan IPA dan terlibat dengan isu-isu IPA sebagai warga reflektif dalam konteks personal, nasional, dan global. Untuk mencapai hal ini diperlukan pembiasaan memecahkan masalah sehari-hari dalam pembelajaran yang berbasis masalah. Saat di bangku sekolah, siswa banyak belajar tentang gizi makanan, alat-alat pencernaan, dan macam-macam penyakit atau kelainan pada sistem pencernaan tetapi masih banyak ditemukan siswa yang kurang memerhatikan kesehatan pencernaannya. Siswa tidak sarapan, banyak jajan sembarangan di depan sekolah, dan makan makanan dengan gizi yang tidak seimbang. Sistem pencernaan yang bermasalah dapat menyebabkan sakit maag, diare, diabetes, kegemukan dan menimbulkan penyakit lainnya. Kesehatan tubuh bergantung pada kondisi usus dan lambung. Refluks esofagitis secara signifikan berhubungan dengan stres psikososial, dan tingkat keparahan refluks esofagitis berkorelasi dengan tingkat stress (Torres et al., 2007; Song et al., 2013). Materi zat aditif dan adiktif juga dipelajari sejak SD sampai SMP, tetapi masih banyak siswa SMP yang membeli makanan dan jajanan yang tidak sehat, mengandung banyak zat aditif yang berbahaya. Guru juga sering menemukan siswa yang merokok. Guru perlu membelajarkan kembali bahaya dari zat adiktif yang terkandung dalam rokok dan risikonya bagi kesehatan khususnya sistem pernapasan. Oleh karena itu, materi sistem pencernaan, zat aditif dan adiktif, dan sistem pernapasan yang dipelajari siswa SMP melalui mata pelajaran IPA sangat cocok menggunakan pembelajaran berbasis masalah.

PBM adalah model pembelajaran yang berpusat kepada siswa. Menggunakan permasalahan dunia nyata maupun masalah kompleks sebagai titik awal dan akhir selama proses pembelajaran (Silver dan Ellina, 2004). Berlangsung aktivitas kolaborasi yang ditandai oleh siswa bekerjasama dan dialog bersama untuk mengembangkan berbagai keterampilan sosial (Kemdikbud, 2014). Menyuguhkan berbagai situasi bermasalah yang autentik dan bermakna kepada siswa yang berfungsi sebagai batu loncatan untuk investigasi (Arends, 2012). PBM menempatkan siswa di pusat persoalan yang autentik dan tidak terstruktur dengan beragam jawaban yang memungkinkan. Belajar berdasarkan masalah adalah belajar berpikir tentang masalah kehidupan riil di sekitar siswa (Wheeler, 2002). Hal ini telah terbukti dapat meningkatkan dan mengembangkan kemampuan berpikir lebih tinggi, siswa berpikir tentang masalah dengan kritis, menganalisis data untuk menyelesaikan masalah, dan membuat keputusan (Nowak, 2001; Sungur dkk, 2006). PBM dipilih karena dapat meningkatkan kemampuan pemecahan masalah, pemahaman akan metode ilmiah, kemampuan berpikir kritis, kesadaran metakognitif, dan kreativitas siswa (Bredderman, 1983; Gorman dkk, 1998; Johnson \& Stewart, 2002; Schneider dkk, 2002; Hattie, 2009; Karmana, 2010; Rohmawati, 2011; Tamri, 2012)

Thinking map membantu guru melihat kemampuan berpikir siswa untuk memecahkan masalah. Tanpa thinking map siswa dapat menjawab benar, tetapi tidak dapat menjelaskan bagaimana memperoleh kebenaran tersebut (Holzman, 2004). Siswa dapat memilih model thinking map yang digunakan sesuai dengan pemikiran mereka sendiri. Hal ini menjadi inovasi dalam sebuah pembelajaran di sekolah. Dengan thinking map semua siswa memiliki bahasa visual verbal, lebih dalam untuk melihat, mengubah, membayangkan, dan meningkatkan penguasaan konsep IPA serta literasi sains dalam pembelajaran pelajaran IPA yang berbasis masalah.

\section{METODE}

Penelitian eksperimen ini untuk mengetahui keefektifan PBM berbantuan thinking map terhadap penguasaan konsep IPA dan literasi sains siswa SMP pada materi sistem pencernaan, zat aditif dan adiktif, dan sistem pernapasan. Penelitian ini merupakan penelitian eksperimen semu dengan pretest posttest control group design. Sampel penelitian ini yaitu siswa kelas VIII C berjumlah 31 siswa sebagai kelas eksperimen yang dibelajarkan dengan model PBM berbantuan thinking map, kelas 8D berjumlah 31 siswa sebagai kelas kontrol positif yang dibelajarkan dengan model pembelajaran PBM saja dan kelas 8A berjumlah 32 siswa sebagai kelas kontrol negatif yang dibelajarkan dengan model pembelajaran selain PBM. Instrumen penelitian berupa tes 25 soal pilihan ganda untuk mengukur ketercapaian siswa terhadap tujuh indikator penguasaan konsep dan 20 soal pilihan ganda untuk mengukur ketercapaian siswa terhadap sembilan indikator literasi sains. 


\section{HASIL}

Hasil penguasaan konsep IPA mencakup lima ranah kognitif, yaitu C1, C2, C3, C4, dan C5. Terdapat peningkatan skor penguasaan konsep IPA siswa baik pada kelas eksperimen maupun kelas kontrol. Peningkatan pada kelas eksperimen sebesar 9,57 dan kelas kontrol sebesar 8,40. Peningkatan pada kelas eksperimen lebih besar daripada kelas kontrol. Hal ini berarti bahwa penguasaan konsep IPA siswa pada materi sistem pencernaan, zat aditif dan sistem pernapasan mengalami perubahan setelah melaksanakan proses pembelajaran. Perbandingan skor rata-rata pretest dan posttest penguasaan konsep IPA kelas eksperimen dan kelas kontrol dapat dilihat pada gambar 1.

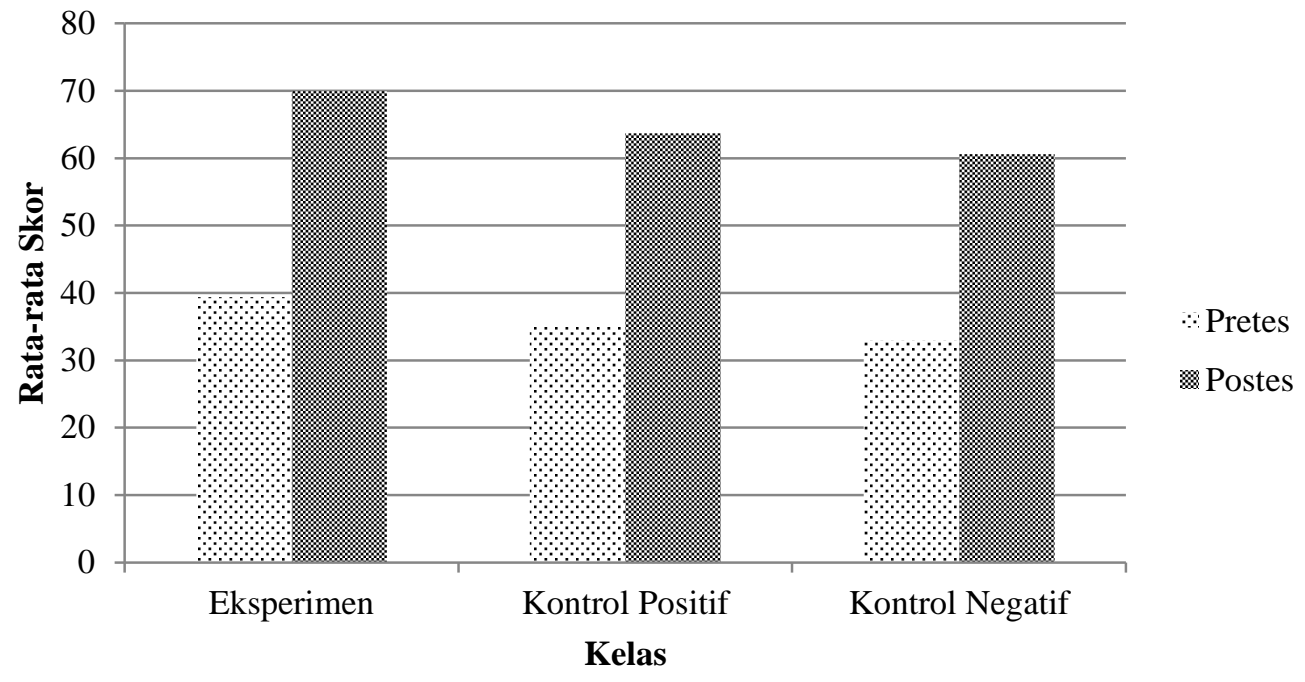

Gambar 1 Skor Rata-Rata Pretest dan Posttest Penguasaan Konsep IPA

Terdapat peningkatan skor literasi sains siswa pada kelas eksperimen maupun kelas kontrol. Peningkatan pada kelas eksperimen sebesar 30,54, kelas kontrol positif sebesar 28,65 dan kelas kontrol negatif sebesar 27,66. Hal ini berarti bahwa kemampuan literasi sains siswa mengalami perubahan setelah melaksanakan proses pembelajaran. Perbandingan skor rata-rata pretest dan posttest literasi sains siswa kelas eksperimen dan kelas kontrol dapat dilihat pada gambar 2.

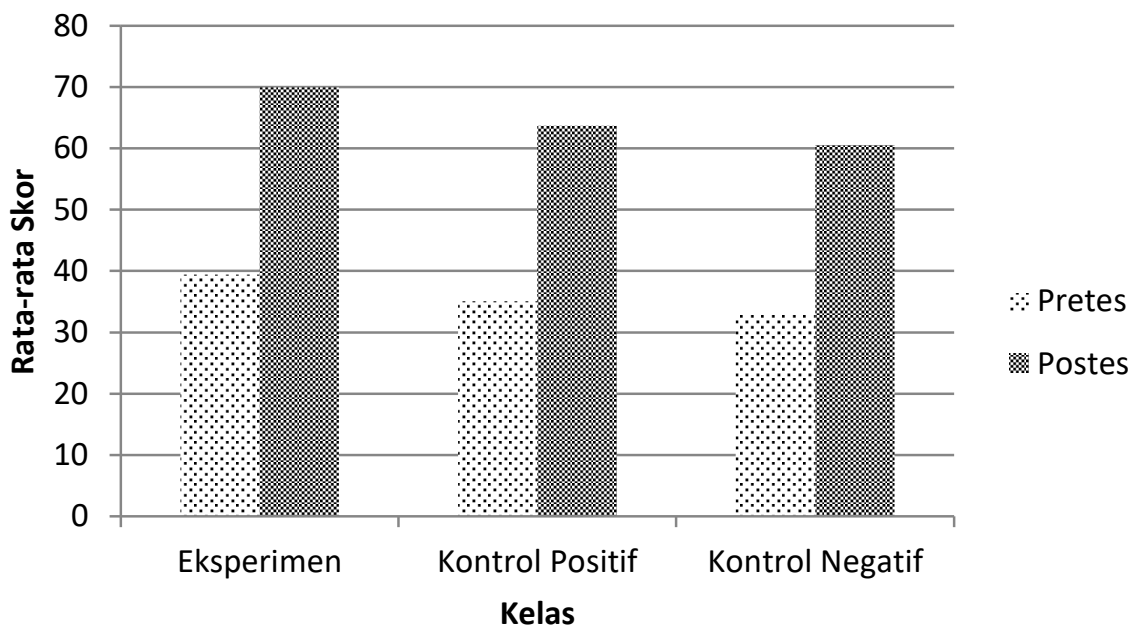

\section{Gambar 2. Skor Rata-Rata Pretest dan Posttest Literasi Sains Siswa}

Thinking map yang telah dibuat oleh siswa pada setiap pokok bahasan dinilai dengan menggunakan rubrik penilaian thinking map yang diadaptasi dari Hyerle \& Larry (2012:268). Penilaian meliputi indikator mengembangkan (ada tidaknya hubungan antar konsep dan banyak jenis thinking map yang dapat dibuat), menjelaskan (banyaknya informasi yang relevan) dan mengintegrasikan (integrasi pengetahuan awal dengan pengetahuan baru dan membuat penerapan konsep baru). Penilaian juga meliputi indikator struktur catatan, bentuk cabang dan warna, isi materi, keterkaitan konsep, penggunaan bahasa dan istilah, 
serta penggunaan gambar dan simbol. Berdasarkan hasil penelitian thinking map yang dibuat oleh siswa kelas eksperimen pada setiap pertemuan selama proses pembelajaran materi sistem pencernaan dapat diketahui nilai rata-rata yang diperoleh siswa sebesar 60 yang termasuk dalam katagori B+. Nilai tertinggi yang diperoleh siswa sebesar 73 termasuk kategori A dan nilai terendah sebesar 45 termasuk kategori C. Rata-rata indikator struktur catatan dan bentuk cabang dan warna thinking map siswa sebesar 1,70 dan 2,88 menunjukkan bahwa siswa telah memahami bentuk penulisan thinking map dengan benar. Rata-rata indikator thinking map siswa pada isi materi sebesar 3,52 dan keterkaitan konsep sebesar 3,56 serta penggunaan bahasa dan istilah sebesar 3,51 menunjukkan bahwa siswa dapat memahami materi yang dipelajari dan menghubungkan konsep-konsep didalamnya dengan bahasa dan istilah yang tepat. Rata-rata indikator penggunaan gambar dan simbol sangat kecil yaitu sebesar 0,1 disebabkan sebagian besar siswa tidak memberi gambar atau simbol pada thinking map karena keterbatasan waktu di kelas dan siswa tidak melakukan perbaikan yang dapat dilakukan baik di sekolah maupun di rumah. Namun demikian, dapat dikatakan bahwa siswa telah membuat thinking map yang baik sesuai dengan indikator penilaian.

Hasil uji hipotesis penguasaan konsep IPA siswa dengan uji ANCOVA menghasilkan nilai signifikansi 0,026 $<0,05$ sehingga $\mathrm{H}_{0}$ ditolak dan hipotesis penelitian diterima. Hal ini berarti bahwa ada perbedaan yang signifikan pada penguasaan konsep IPA siswa kelas VIII yang dibelajarkan melalui PBM berbantuan thinking map dan PBM saja, dimana nilai rata-rata penguasaan konsep IPA siswa kelas eksperimen lebih tinggi dibandingkan dengan kelas kontrol. Hasil uji Lanjut dengan Beda Nyata Terkecil (BNT) dapat dijelaskan bahwa kelas dengan PBM berbantuan thinking map tidak berbeda nyata dengan kelas dengan PBM, namun berbeda nyata dengan kelas konvensional. Hasil uji Cohen's menunjukkan bahwa ketiga perlakuan memiliki efek ukuran besar, dengan kontrol positif (PBM) paling besar 4.73, diikuti kelas eksperimen sebesar 3.81 (PBM berbantuan thinking map), dan terakhir kontrol negatif (konvensional) sebesar 3.48, artinya ada efek yang besar pada perlakuan PBM berbantuan thinking map terhadap penguasaan konsep siswa.

Hasil uji hipotesis literasi sains siswa dengan uji ANCOVA menghasilkan nilai signifikansi 0,000 $<0,05$ sehingga $\mathrm{H}_{0}$ ditolak dan hipotesis penelitian diterima. Hal ini berarti bahwa ada perbedaan yang signifikan pada literasi sains siswa kelas VIII yang dibelajarkan melalui PBM dengan thinking map, dimana nilai rata-rata literasi sains siswa kelas eksperimen lebih tinggi dibandingkan dengan kelas kontrol. Hasil uji Lanjut dengan BNT dapat dijelaskan bahwa kelas dengan PBM berbantuan thinking map tidak berbeda nyata dengan kelas dengan PBM, namun berbeda nyata dengan kelas konvensional. Berdasarkan hasil perhitungan effect size, diketahui bahwa pengaruh PBL berbantuan Thinking map terhadap penguasaan konsep IPA sebesar 3.81. Hal ini menunjukkan bahwa pengaruh PBL berbantuan Thinking map terhadap penguasaan konsep IPA siswa termasuk dalam kategori besar. Pengaruh PBL berbantuan Thinking map terhadap literasi sains sebesar 4,13. Hal ini menunjukkan bahwa pengaruh PBL berbantuan Thinking map terhadap literasi sains tergolong besar.

\section{PEMBAHASAN}

Berdasarkan hasil analisis data penguasaan konsep IPA siswa yang diperoleh dalam penelitian ini menunjukkan nilai signifikansi $0,018<0,05$ sehingga $\mathrm{H} 0$ ditolak dan hipotesis penelitian dapat diterima. dengan demikian terdapat perbedaan penguasaan konsep IPA antara siswa yang dibelajarkan melalui model pembelajaran PBM dengan bantuan thinking map dan siswa yang dibelajarkan dengan model pembelajaran PBM. Model pembelajaran PBM dengan bantuan thinking map memberikan pengaruh nyata terhadap kemampuan penguasaan konsep IPA siswa. Hal ini karena pembelajaran PBM dianggap efektif untuk membantu siswa memperoleh penguasaan konsep IPA secara ilmiah karena siswa dituntut terlibat langsung untuk mengajukan pertanyaan terkait masalah-masalah dalam kehidupan sehari-hari, menguji hipotesis, melakukan pengamatan atau investigasi dan membuat kesimpulan berdasarkan data dan bukti selama proses pembelajaran berlangsung.

Skor rata-rata pos tes penguasaan konsep IPA pada kelas eksperimen yang belajar dengan menggunakan model pembelajaran PBM dengan bantuan thinking map lebih tinggi dibandingkan dengan PBM tanpa thinking map. Hal ini dikarenakan adanya keselarasan antara sintaks PBM dengan teknik thinking map yang menekankan pada proses belajar dan proses pembentukan pengetahuan di dalam diri siswa. Pada model PBM dengan bantuan thinking map mengajarkan siswa bagaimana cara mengonstruksi pengetahuannya sendiri berdasarkan fakta yang diperoleh selama proses pembelajaran. Dengan demikian Siswa memiliki kesempatan untuk membangun pengetahuan di dalam pikirannya sesuai hasil investigasinya sehingga pengetahuan yang diperoleh lebih bermakna bagi siswa.

Thinking map yang terpenting adalah bagaimana kemampuan siswa untuk menunjukkan kemampuan keterampilan berpikir. Siswa lebih merasakan dapat terhubung antara materi yang dipelajari sebagai akibat dari proses pemetaan pemikiran yang ada untuk dibuat di sebuah kertas. Selain itu, siswa dibimbing oleh guru untuk meningkatkan hubungan antara materi dan pengalaman yang siswa rasakan di kehidupan sehari-hari (Costa \& Kallik, 2008). Thinking map sangat menguntungkan bagi siswa dan guru karena dapat menuangkan ide dan konsep (Long \& Carlson, 2011). Melalui thinking map, semua siswa memiliki bahasa kognisi lisan dan tulisan sehingga siswa dapat melihat, membaca hasil pikirannya sendiri, mengubah, membayangkan, dan meningkatkan kemampuan berpikirnya (Hyerle \& Alper, 2012). Selain itu, pemahaman tentang konsepsi tujuan lebih sering muncul pada tulisan siswa ketika siswa memiliki kesempatan untuk menjelaskan ide-ide baru mereka secara lisan dan tertulis (Fellows, 1994). Hal tersebut diperkuat oleh Alikhan (2014) yang mengemukakan bahwa Thinking map merupakan representasi visual pemikiran, membantu siswa melihat jalur belajar mereka sendiri atau proses berpikir yang dimanfaatkan untuk memecahkan masalah. Thinking map mendorong proses pembelajaran, meningkatkan kinerja siswa, memungkinkan guru untuk memantau dan mengukur kemajuan siswa, dan membuat informasi dan belajar lebih bermakna. Dengan demikian, penggunaan 
thinking map dalam proses pembelajaran dapat memberikan keluasan bagi siswa untuk menerima dan memahami materi pembelajaran yang disampaikan oleh guru di sekolah.

Berdasarkan hasil analisis literasi sains yang diperoleh dalam penelitian ini menunjukkan nilai signifikansi sehingga H0 ditolak dan hipotesis penelitian diterima. Dengan demikian, terdapat perbedaan literasi sains antara siswa yang dibelajarkan melalui model PBM dengan bantuan thinking map dan siswa yang dibelajarkan dengan model PBM saja. Hal ini berarti bahwa PBM dengan bantuan thinking map memberikan pengaruh yang lebih baik terhadap peningkatan literasi sains siswa dibandingkan dengan PBM. Beberapa penelitian sudah menunjukkan bahwa PBM dapat meningkatkan kemampuan pemecahan masalah, pemahaman akan metode ilmiah, kemampuan berpikir kritis, kesadaran metakognitif, dan kreativitas siswa (Bredderman, 1983; Gorman dkk, 1998; Johnson \& Stewart, 2002; Schneider dkk, 2002; Hattie, 2009; Karmana, 2010; Rohmawati, 2011; Tamri, 2012). Siswa yang diajar dengan PBM sangat termotivasi, mencapai pemahaman yang lebih dalam dan kompleks, dan dapat menerapkan pengetahuan ke situasi baru (Gijbels dkk, 2005; Hmelo dkk, 2006). Pelaksanaan PBM mendorong siswa untuk berpikir kritis melalui perencanaan, diskusi, menyatakan pertanyaan dan masalah, dan menganalisis serta memberikan solusi pemecahan masalah-masalah lingkungan (Asyari, 2016).

Thinking map yang dibuat oleh siswa pada setiap kegiatan pembelajaran merupakan catatan yang orisinil karena thinking map yang dihasilkan oleh setiap siswa tidak ada yang sama persis baik dari segi penulisan warna maupun konsep meskipun materi yang dibahas sama. Hal ini dikarenakan setiap siswa memiliki pengalaman dan kemampuan kreativitas berbeda (El Mona \& El Khalick 2008) sehingga thinking map yang dihasilkan oleh siswa satu dengan siswa lainnya menjadi berbeda pada materi yang sama. Selain itu, kemampuan siswa untuk memahami konsep juga menentukan thinking map yang dibuat oleh siswa. Pembuatan thinking map pada penelitian ini dilakukan pada langkah orientasi masalah dan mengembangkan dan meyajikan hasil karya. Pada langkah orientasi masalah thinking map dapat memfokuskan siswa pada pokok bahasan yang dipelajari. Belajar dengan menggunakan thinking map dapat membuat siswa lebih mampu memfokuskan perhatian pada proses asimilasi, mengorganisasi, akomodasi dan mengingat informasi serta dapat memberikan sebuah pemahaman suatu konsep yang lebih utuh karena dapat menciptakan kesan yang lebih lama diingat (Elmona \& El Khalick, 2008).

Penggunaan thinking map pada langkah mengembangkan dan meyajikan hasil karya dapat membantu siswa merumuskan kesimpulan dan mempermudah siswa untuk lebih memahami materi yang dipelajari. Evrekli dkk. 2009 menjelaskan bahwa thinking map efektif digunakan untuk membantu siswa meski dengan beragam latar belakang mengonstruksi pemahaman siswa terhadap sains dan teknologi. Thinking map dapat membantu siswa mengingat poin-poin penting yang diperlukan siswa untuk dipahami lebih lanjut. Thinking map pada akhir pembelajaran diharapkan dapat membantu siswa memenangkan konsep-konsep yang divisualisasikan secara menarik sehingga berfungsi sebagai sarana untuk memantapkan materi yang telah dipelajari siswa dan membantu siswa dalam belajar. Thinking map mendorong proses pembelajaran, meningkatkan kinerja siswa, memungkinkan guru untuk memantau dan mengukur kemajuan siswa, dan membuat informasi dan belajar lebih bermakna (Alikhan, 2014). Selain itu, Thinking map dapat mengembangkan kreativitas siswa (Elmona \& Elkhalick, 2008).

Berdasarkan pembahasan yang telah diuraikan pada hal sebelumnya, maka dapat dinyatakan bahwa PBM dengan bantuan thinking map memberikan pengaruh yang positif terhadap penguasaan konsep IPA dan literasi sains siswa. Langkahlangkah pembelajaran berbasis masalah membantu penguasaan konsep IPA siswa dan thinking map membantu siswa dalam mengorganisasikan materi pemahaman asosiasi materi dan memberikan gambaran visual-verbal. Thinking map merupakan media belajar yang sangat cocok untuk tipe orang dengan gaya belajar visual-verbal.

\section{SIMPULAN}

Ada perbedaan signifikan pada penguasaan konsep IPA antara siswa kelas VIII SMPN 5 Jombang yang dibelajarkan melalui PBM dan PBM dengan thinking map. Hasil penghitungan uji beda ancova menunjukkan nilai signifikansi $0,072<0,05$ yang berarti terdapat perbedaan yang signifikan pada penguasaan konsep IPA siswa kelas eksperimen dan kelas kontrol. Ada perbedaan yang dihasilkan signifikan pada kemampuan literasi sains antara siswa kelas VIII SMPN 5 Jombang yang dibelajarkan Melalui PBM dan PBM dengan thinking map. Hasil penghitungan uji beda ancova menunjukkan nilai signifikansi $0.023<0,05$ yang berarti terdapat perbedaan yang signifikan pada literasi sains siswa kelas eksperimen dan kelas kontrol.

Thinking map berpengaruh terhadap penguasaan konsep IPA antara siswa kelas VIII SMPN 5 Jombang yang dibelajarkan melalui PBM dan PBM dengan thinking map. Nilai rata-rata indikator keterkaitan konsep pada thinking map siswa sebesar 2,51 atau 84,34\% siswa mampu memahami keterkaitan konsep IPA. Hasil perhitungan effect size menunjukkan nilai sebesar 0,54 yang berarti pengaruh thinking map terhadap peningkatan penguasaan konsep IPA siswa termasuk dalam kategori sedang.

Thinking map berpengaruh terhadap literasi sains antara siswa kelas VIII SMPN 5 Jombang yang dibelajarkan melalui PBM dan PBM dengan thinking map. Nilai thinking map yang diperoleh siswa rata-rata sebesar 69 termasuk dalam kategori B+ yang berarti siswa mampu membuat thinking map dengan baik. Hasil penghitungan effect size menunjukkan nilai sebesar 0,54 yang berarti pengaruh thinking map terhadap peningkatan literasi sains siswa tersebut termasuk di dalam kategori sedang. Analisis yang lebih mendalam pada hasil thinking map yang dibuat oleh siswa untuk mengetahui pengaruhnya terhadap penguasaan konsep IPA dan literasi sains pada masing-masing siswa. Perlu dilakukan penelitian korelasi untuk dapat mengetahui adanya hubungan antara penguasaan konsep IPA dan literasi sains siswa. 


\section{DAFTAR RUJUKAN}

Anderson, D. W., Vault, V. D., \& Dickson, C. E. (1999). Problems and Prospects for the Decades A Head: Competency Based Teacher Education. Berkeley: McCutchan Publishing Co.

Arends, R. I. (2012). Learning to Teach Ninth Edition. New York: Mc Graw Hill Companies.

Asyari, M., Al Muhdhar, M. H. I., Susilo, H., \& Ibrohim. (2016). Improving Critical Thinking Skills Through the Integration of Problem Based Learning and Group Investigation. International Journal for Lesson and Learning Studies, 5(1), 3644.

Bredderman, T. (1983). Effects of Activity-Based Elementary Science on Student Outcomes: A Quantitative Synthesis. Review of Educational Research, 53(4), 499-518.

Brown, N. J., Furtak, E. M., Timms, M., Nagashima, S. O., \& Wilson, M. (2010). The Evidence-Based Reasoning Framework: Assessing Scientific Reasoning. Educational Assessment, 15(3-4), 123-141.

Oliver, J. S., Jackson, D. F., Chun, S., Kemp, A., Tippins, D. J., Leonard, R., ... \& Rascoe, B. (2001). The Concept of Scientific Literacy: A View of the Current Debate as an Outgrowth of the Past Two Centuries. Electronic Journal of Literacy through Science, 1(1).

Departemen Pendidikan Nasional. (2006). Standar Kompetensi Mata Pelajaran Biologi Sekolah Menengah Atas dan Madrasah Aliyah. Jakarta: Depdikbud

Gijbels, D., Dochy, F., Van den Bossche, P., \& Segers, M. (2005). Effects of Problem-Based Learning: A Meta-Analysis from the Angle of Assessment. Review of Educational Research, 75(1), 27-61.

Hasnunidah, N., Susilo, H., Irawati, M. H., \& Sutomo, H. (2015). Argument-Driven Inquiry with Scaffolding as the Development Strategies of Argumentation and Critical Thinking Skills of Students in Lampung, Indonesia. American Journal of Educational Research, 3(9), 1185-1192.

Hattie, J. A. C. (2009). Visible Learning: A Synthesis of Over 800 Meta-Analysis Relating to Achievement. New York: Routledge.

Hmelo-Silver, C. E., \& Barrows, H. S. (2006). Goals and Strategies of a Problem-Based Learning Facilitator. Interdisciplinary Journal of Problem-based Learning, 1(1), 21-39.

Holbrook, J., \& Rannikmae, M. (2009). The Meaning of Scientific Literacy. International Journal of Environmental and Science Education, 4(3), 275-288.

Hobson, A. (2001). Teaching Relevant Science for Scientific Literacy. Journal of College Science Teaching, 30(4), 238 -243.

Holzman, S. (2004, April). Thinking Maps: Strategy-Based Learning for English Language Learners (and others). In Paper Presented al $13^{\text {th }}$ Annual Administrator Conference (pp. 1-8).

Johnson, E. B. (2002.) Contextual Teaching and Learning. Thousand Oaks: Corwin Press, Inc.

Karmana, I. W. (2010). Pengaruh Strategi PBL dan Integrasinya dengan STAD terhadap Kemampuan Pemecahan Masalah, Kemampuan Berpikir Kritis, Kesadaran Metakognitif, dan Hasil Belajar Biologi pada Siswa Kelas X SMA Negeri 4 Mataram. Tesis tidak diterbitkan. Universitas Negeri Malang, Malang.

Kemdikbud. (2014). Standar Proses Pendidikan Dasar dan Menengah. Jakarta: Depdiknas.

Ku, K. Y., Ho, I. T., Hau, K. T., \& Lai, E. C. (2014). Integrating Direct and Inquiry-Based Instruction in the Teaching of Critical Thinking: An Intervention Study. Instructional Science, 42(2), 251-269.

Larmer, J., \& Mergendoller, J. R. (2010). Seven Essentials for Project-Based Learning. Educational Leadership, 68(1), 34 -37.

Liu, X. (2009). Special Issue on Science Literacy. International Journal of Environment \& Sciene Education, 4(3), $1-11$.

OECD. (2012). Assessing Scientific, Reading, and Mathematical Literacy. A Framework for PISA 2012. Paris: OECD Publishing

Rohmawati. (2011). Pengaruh Strategi PBL Berbasis Multimedia dan Kemampuan Akademik terhadap Kemampuan Pemecahan Masalah, Penguasaan Konsep, Sikap, dan Keterampilan Pengelolaan Lingkungan Siswa SMK Negeri 2 Bondowoso. Tesis tidak diterbitkan. Universitas Negeri Malang, Malang.

Sari, I. M., Sumiati, E., \& Siahaan, P. (2013). Analisis Kemampuan Berpikir Kreatif Siswa SMP Dalam Pembelajaran Pendidikan Teknologi Dasar (PTD). Jurnal Pengajaran MIPA, 18(1), 60-68.

Shwartz, Y., Ben-Zvi, R., \& Hofstein, A. (2006). The Use of Scientific Literacy Taxonomy for Assessing the Development of Chemical Literacy Among High-School Students. Chemistry Education Research and Practice, 7(4), 203 -225.

Song, E. M., Jung, H. K., \& Jung, J. M. (2013). The Association Between Reflux Esophagitis and Psychosocial Stress. Digestive Diseases and Sciences, 58(2), 471-477.

Sungur, S., Tekkaya, C., \& Geban, Ö. (2006). Improving achievement through problem-based learning. Journal of Biological Education, 40(4), 155-160.

Tamri. (2012). Pengaruh Strategi PBL dan Kooperatif STAD terhadap Kemampuan Pemecahan Masalah, Berpikir Kritis, Kesadaran Metakognitif dan Penguasaan Konsep Biologi Kelas X SMA Negeri 9 Balikpapan TA 2011/2012. Tesis tidak diterbitkan. Universitas Negeri Malang, Malang.

Torres, S. J., \& Nowson, C. A. (2007). Relationship Between Stress, Eating Behavior, and Obesity. Nutrition, 23(11-12), 887894. 
Wenning, C. J. (2007). Assessing Inquiry Skills as a Component of Scientific Literacy. Journal of Physics Teacher Education Online, 4(2), 21-24.

Yates, M., Cheong, E., Luben, R., Igali, L., Fitzgerald, R., Khaw, K. T., \& Hart, A. (2014). Body Mass Index, Smoking, and Alcohol and Risks of Barrett's Esophagus and Esophageal Adenocarcinoma: A UK Prospective Cohort Study. Digestive Diseases and Sciences, 59(7), 1552-1559. 